\title{
Barriers to ISO 9001 Implementation in Moroccan Organizations: Empirical Study
}

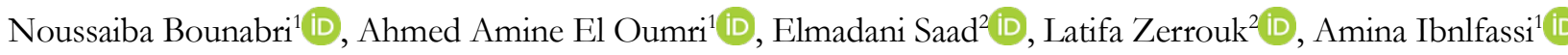 \\ ${ }^{1}$ Université Hassan 1er, Faculté des Sciences et Techniques de Settat \\ Laboratoire des Sciences de l'Environnement et de Développement (SED) (Morocco) \\ ${ }^{2}$ Université Hassan 1er, Faculté des Sciences et Techniques de Settat \\ Laboratoire Physico-chimie des Procédés et des Matériaux (PCPM) (Morocco)
}

noussaibabounabri@gmail.com,_aa.eloumri@gmail.com,saadelmadani73@gmail.com,zelatifa@yahoo.fr,aibnlfassi@yahoo.fr

Received: September 2017

Accepted: December 2017

\section{Abstract:}

Purpose: The purpose of this paper is to explore obstacles to ISO 9001 quality management system implementation in Moroccan firms.

Design/methodology/approach: A questionnaire survey has been conducted among a heterogeneous sample of 200 organizations, operating in different sectors in Morocco, yielding a response rate of $57.5 \%$. The authors have studied barriers to quality initiatives in general and obstacles to QMS implementation in particular through an extensive literature review. Questions related to profiles of respondents, reasons of seeking certification, external consultancy and barriers to ISO 9001 implementation experienced by surveyed organizations. For the purpose of this study, authors considered three categories of quality inhibiting factors: organizational, technical and costs related barriers.

Findings: Results indicate that surveyed companies sought ISO 9001 certification mainly for marketing reasons and experienced many difficulties during the implementation process. Barriers reported by respondents were mostly organizational. Resistance to change headed the list according to participants' opinion. Also, findings highlighted the prominence of bureaucracy and poor interdependence between departments in organizations. Lack of communication, poor top management commitment and insufficient trainings were also ascertained to be obstacles to QMS implementation in Morocco.

Originality/value: Earlier studies were led by different researchers in different countries about barriers to quality initiatives in general and to ISO 9001 implementation in particular. Few of those studies were conducted in Arab speaking countries but no research has been carried in Morocco. This study on obstacles to QMS implementation in Morocco will help in completing the jigsaw of difficulties faced by organizations worldwide when preparing to ISO 9001 certification.

Research limitations/implications: This research is limited by the geographic context of the study Morocco, although results can be extrapolated to Arab speaking countries in general.

Practical implications: The findings of this paper provide Moroccan managers with a practical understanding of the factors that are likely to obstruct ISO 9001 QMS implementation. Managers should overcome these barriers to achieve a successful implementation and higher QMS performance.

Keywords: Quality management, ISO 9001, questionnaire survey, Morocco 


\section{Introduction}

In order to remain competitive, organizations must improve continuously their quality management strategies. One of the main foundations of a successful management strategy is an effective quality management system.

Singhal and Singhal (2012) stated that ISO 9001, first introduced in 1987 by International organization of standardization ISO among the ISO 9000 series (Such as ISO 9000, ISO 9002. ISO 9003 and ISO 9004), is an international standard that assists more than one million organizations around the world by providing a set of requirements for developing and demonstrating an effective documented QMS.

According the ISO survey (2015) 1033936 ISO 9001 certificates were issued in 2015 in 201 countries and economies around the world with an increase of 5461 in the number of certificates and 14 in the number of countries compared to 2013 as showed in Figure 1. European countries head the ranking with 439477 certified organizations while Middle East and Africa lay down the list with respectively 22761 and 12154 ISO 9001 certifications.

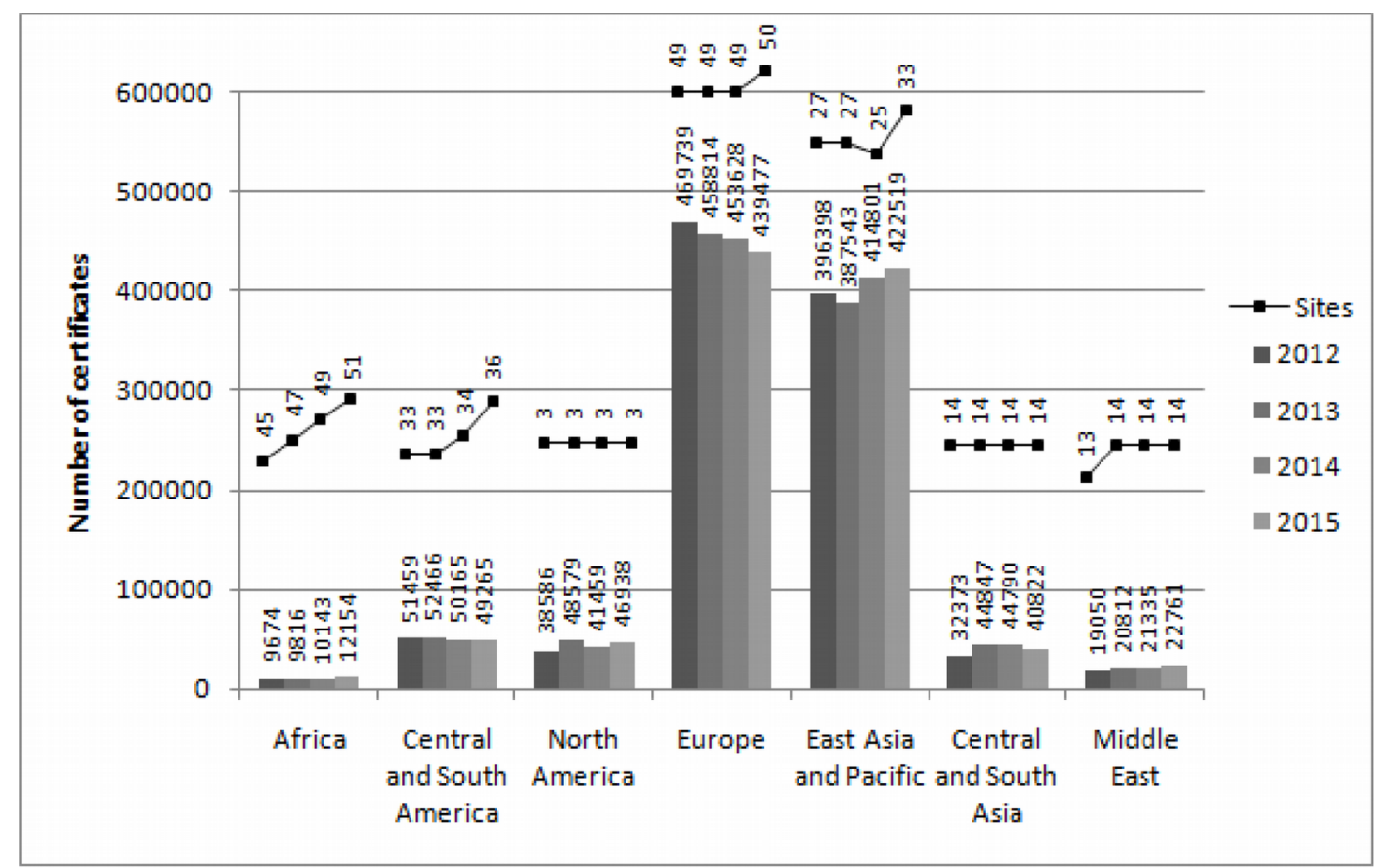

Figure 1. ISO 9001 annual growth in number of certificates and sites worldwide

Despite the fact that the QMS implementation is relatively new to the Arab world and has occurred in that region more slowly than in Western and Asian countries as stated by Zairi and Youssef (1995), according to ISO survey (2015) numbers of Arab ISO 9001 certifications are growing significantly each year as shown in (Figure 2).

Figure 2 presents the numbers of certification in the Arab countries in a descending order. The country heading the Top ten ranking with the larger number of certificates in 2015 is United Arab Emirates followed by Saudi Arabia whereas morocco comes in the fifth place with 969 certified organizations.

Although implementing a QMS may appear simple at first, especially given the increasing numbers of ISO 9001 certified organizations over years there are so many barriers to overcome when taking the decision of implementation. Certification does not guarantee a fluent QMS implementation, as the process brings inevitably change to the organization. Many forces acting against it create barriers, such as resistance, commitment and flexibility issues when the implemented change is not managed the best way possible.

Despite the amount of research into QMS and TQM implementation barriers, most of empirical studies has been carried out by different authors in developed countries, among others, Mo and Chan (1997), Carlsson and Carlsson (1996), Lipovatz, Stenos and Vaka (1999), Fuentes, Benavent, Moreno, Cruz \& Pardo del Val (2000), Glover and Siu (2000), just few in the Arab world such as Al-Khalifa and Aspinwall (2000), Curry and Kadasah (2002), Sharif 
(2005), Hesham and Magd (2007), Al-Najjar and Jawad (2011) and no research study has been conducted on the topic in Morocco.

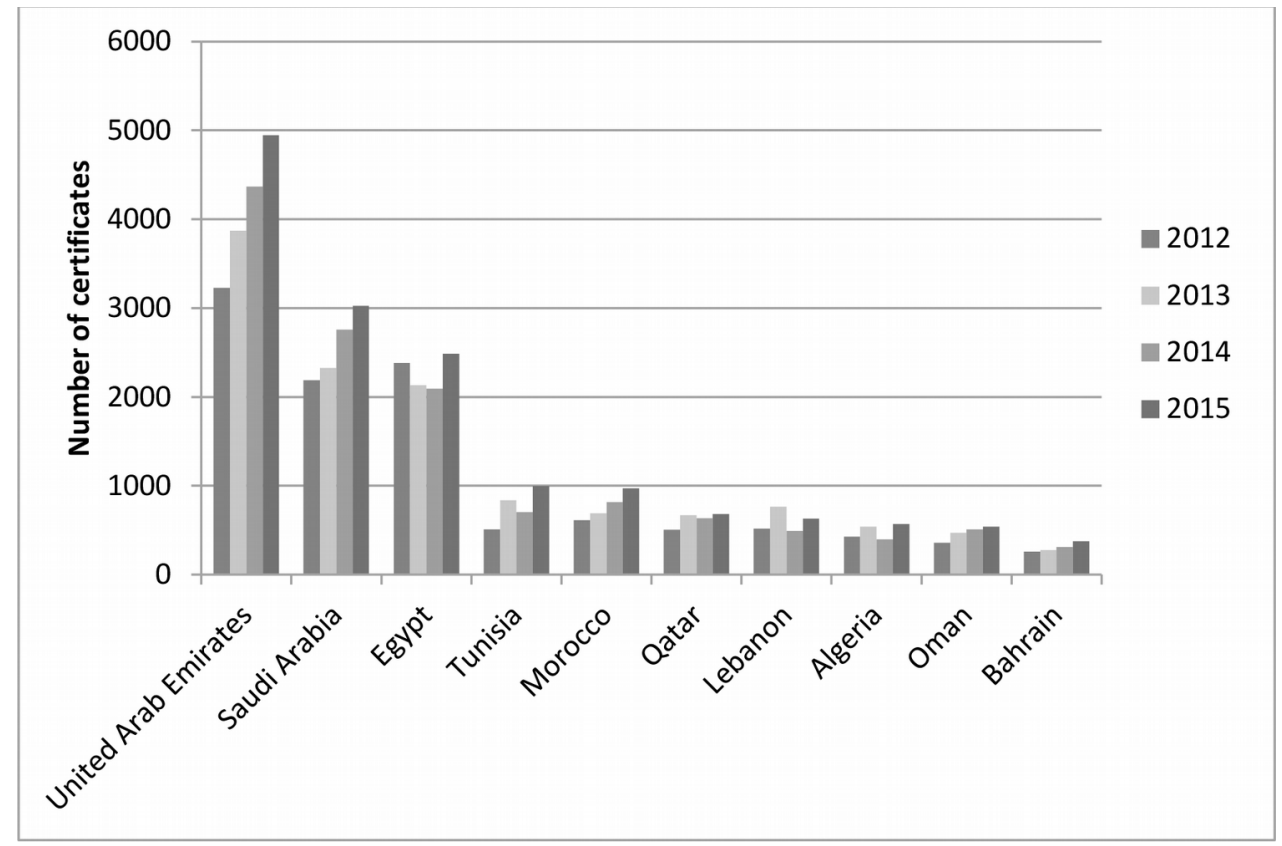

Figure 2. Annual growth in numbers of certificates in Arab speaking countries

The purpose of this empirical study is to highlight barriers of ISO 9001:2008 implementation in Morocco. We expect that the findings will help Moroccan organizations in particular, and Arab organizations in general, willing to get ISO 9001 certification to prepare themselves properly in order to overcome obstacles that are likely to occur during the change process and furthermore, to ensure an effective QMS implementation process and improve quality management performance.

On the basis of above discussion, the following research questions arise;

1. What are motivations to ISO 9001 implementation in Moroccan organizations?

2. What are the most important barriers that obstruct ISO 9001 implementation in Moroccan organizations?

\section{Literature Review}

\subsection{ISO 9001: Overview}

Quality management is the process for achieving quality as stated by Knowles (2011). World's most widely used standard for quality management is ISO 9001. As stated by Singhal and Singhal (2012), international organization of standardization introduced in 1978 ISO 9000 series, providing a set of requirements and guidelines for developing and demonstrating an effective documented quality management system.

The first version, divided to three parts, provided three models of quality management system; Part 1: Model for quality assurance in design, development, production, installation, and servicing, Part 2: Model for quality assurance in production, installation, and servicing, Part 3: Model for quality assurance in final inspection and test, and was mainly accessible for manufacturers and recognized for being immensely incomplete. (Tricker, 2016).

As the popularity and the use of ISO 9000:1987 grew, in 1994, ISO realized that calling three different documents by the same name lead to confusion, so they reproduced the three «parts» and changed the names to respectively ISO 9001:1994, ISO 9002:1994 and ISO 9003:1987. Other numerous changes were intended to make the requirements more explicit and the standard easier to read. (Tricker, 2016).

The 2000 version was considered a revolution to the standard and brought radical changes to the previous version. First, ISO 9001, ISO 9002 and ISO 9003 became only one standard which was ISO 9001:2000, second, ISO 
abandoned the 20 sections heavy structure for just five chapters and finally many requirements were omitted, and new ones were introduced.

The fourth edition of ISO 9001, published in 2008 was more of an evolution and brought minor changes of little concern to managers. It clarified the same requirements of its predecessor, was easier to use and recognized for improving consistency with other management standards such as ISO 14001. (Tricker, 2016).

During the last years, we were witnessing a greater globalization, organizations were moving more towards service economy, supporting not only the great varieties of products available in the market but also the increasingly complex supply chains. Therefore, another revision of ISO 9001 standard in 2015 was crucial to reflect these evolutions. ISO released the ISO 9001:2015 edition 15 September 2015, with the following major changes (Fonseca, 2015):

- A common high-level structure;

- Leadership replaced the previous edition concept of management responsibility;

- The concept of context of the organization;

- The adoption of Risk-based-thinking;

- A reinforced emphasis on process approach and intended results;

- The concept of improvement replaced continual improvement,

- The consideration of change management and knowledge management;

The high-level structure with identical core text, terms, and definitions, was adopted, and used for all ISO management systems standards to enhance compatibility of standards, making it easier to implement new standards and integrating them into a management system.

In addition, the new ISO 9001 expects more leadership and commitment from top management; he is to adopt a more proactive approach to quality management and to take more accountability for the effectiveness of the QMS.

Context of the organization is also a new requirement in ISO 9001, stating an organization must consider both the internal and external issues that can impact its strategic objectives and the planning of the QMS. If there are changes in the context of the organization, in needs or trends, or in the relevant requirements of the relevant interested parties, the organization's quality policy need to be reviewed, and the QMS changes should be planned and implemented.

Moreover, in the context of ISO 9001:2015, risk based thinking requires that, both at organizational and process level, risks and opportunities which may affect the QMS and its intended results, must be identified and managed. This new approach replaces what was called preventive action in the previous standard version. In previous editions of ISO 9001, a clause on preventive action was separated from the whole, in the latest edition, prevention is inherent in all aspects of a quality management system, it is built in when the management system is risk based.

The new version reduces emphasis for prescriptive requirements and documentation with stronger focus on the process approach and intended QMS results.

Also, the concept of improvement replaced continual improvement allowing for periodic breakthroughs, reactive change or reorganization, or other sorts of disruptive improvements.

And finally, according to ISO 9001:2015, changes need to be managed both at strategic and the operational level, across the organization, and those that are necessary to ensure that products or services continue to meet their specified requirements need to be controlled. The objectives to be achieved with the changes must be defined, the positive (and negative) implications identified, and the impacts should be accessed. It should be confirmed that the necessary resources and organizational knowledge are available and that the QMS integrity is checked and assured;

We can conclude that ISO 9001:2015 edition highlights the need for managing change, when compared with the previous ISO 9001:2008. Therefore, organizations need to properly manage change to be able to effectively improve their processes and business results, as Fonseca and Domingues (2017) reported in their survey study among a representative sample of IRCA auditors worldwide. 
Only few studies on the experience of ISO 9001:2015 implementation were available, researchers were more interested by the challenge of risk consideration which was the biggest change of the new 2015 edition. Rybski, Jochem and Homma (2017) held empirical study on status of preparation for ISO 9001:2015 to investigate the current status of fulfillment of the additional requirements especially the Risk based approach in German companies. Most German companies did not consider themselves well prepared due to insufficient knowledge about the new requirements included in the revised ISO9001 standard regarding risk-based thinking, the main challenge being related to the analysis and assessment of risks. Lack of competence regarding risk assessment was also ascertained to be prominent in Chiarini (2017) study among a sample of 28 certification bodies experts and quality managers from European manufacturing SMEs as results showed that the most taken into account categories of risk sources were lack of risk-based assessment, poorly trained workers and lack of skills and awareness along with internal production and supplier nonconforming products.

\subsection{Barriers to Quality Initiatives}

Given that implementing ISO 9001 is intended to fix business processes inconsistencies through implementing a new system, it brings inevitably change to the organization. Change is an important part of business for several reasons i.e. competitiveness improvement, organizational renewal, international standards, performance maximization, innovation and technology. When an organization is experiencing change, and goes through a transformation that alters or restructures major parts of its sections, it's called an organizational change. (Zorn, Christensen \& Cheney, 1999). As stated by Hiatt and Creasey (2012), in order to have a successful organizational change, a good change management is important to ensure to get the desired results. Akdeniz (2014) reported that change management is a specific approach of management by using specific technics and tools to ensure a successful change implementation, based on prosci definition of change management as a set of processes and tools used to lead the people side of change in order to attain the desired results.

When implementing change, there are always barriers that are involved, as Gill (2003) quoted, such as lack of communication, lack of top management commitment, misunderstanding of the aims and process of change and resistance.

While Ackerman-Anderson and Anderson (2010) reported that leaders and employees have to integrate personal changes related to culture, behavior and mindset in organizational change to prevent failure, Paton and McCalman (2008) argued that one of the important successful change guarantors is a shared perception amongst people affected by change, regarding related issues and implications and a strong involvement and commitment to achieve desired outcome.

As for implementing quality initiatives in general and implementing ISO 9001 QMS in particular, Table 1 shows the important barriers identified by various authors.

\begin{tabular}{|l|l|l|l|}
\hline Authors & Research method & Country and sample & Identified Barriers \\
\hline $\begin{array}{l}\text { Carlsson \& } \\
\text { Carlsson (1996) }\end{array}$ & $\begin{array}{l}\text { Questionnaire } \\
\text { survey }\end{array}$ & $\begin{array}{l}\text { - Time and resources consumption in the process of } \\
\text { implementation } \\
\text { 214 ISO certified } \\
\text { Swedish companies }\end{array}$ & $\begin{array}{l}\text { - Cumbersome and bureaucratic documentation } \\
\text { - Difficulties in making the quality system understood } \\
\text { and accepted } \\
\text { - Choosing a suitable level for documentation }\end{array}$ \\
\hline Masters (1996) & $\begin{array}{l}\text { Extensive literature } \\
\text { review }\end{array}$ & USA & $\begin{array}{l}\text { - Lack of management commitment } \\
\text { - Poor knowledge } \\
\text { - Inability to change } \\
\text { - Inadequate organizational culture } \\
\text { - Improper planning of the implementation process }\end{array}$ \\
\hline
\end{tabular}




\begin{tabular}{|c|c|c|c|}
\hline Authors & Research method & Country and sample & Identified Barriers \\
\hline $\begin{array}{l}\text { Ngai \& Cheng } \\
\text { (1997) }\end{array}$ & $\begin{array}{l}\text { Principal } \\
\text { component analysis } \\
\text { and } \\
\text { correspondence } \\
\text { analysis }\end{array}$ & $\begin{array}{l}179 \text { companies in } \\
\text { Hong Kong }\end{array}$ & $\begin{array}{l}\text { - Cultural and employee barrier } \\
\text { - Infrastructure barrier } \\
\text { - Managerial barrier } \\
\text { - Organizational barrier }\end{array}$ \\
\hline $\begin{array}{l}\text { Mo \& Chan } \\
(1997)\end{array}$ & $\begin{array}{l}\text { Questionnaire } \\
\text { survey+ case } \\
\text { studies }\end{array}$ & Australia & $\begin{array}{l}\text { - Difficulty to learn and implement the standard } \\
\text { - Unavailability of assistance to implementation } \\
\text { - Unavailability of staff having alreadytheir «own jobs» } \\
\text { - Difficulty of making extensive changes to the existing } \\
\text { system }\end{array}$ \\
\hline $\begin{array}{l}\text { Erdal \& Gosh } \\
(1997)\end{array}$ & $\begin{array}{l}\text { Questionnaire } \\
\text { survey }\end{array}$ & 73 turkish companies & $\begin{array}{l}\text { - Lack of understanding importance of certification } \\
\text { - Unwillingness to change from the existing system } \\
\text { - Difficulty in understanding requirements }\end{array}$ \\
\hline $\begin{array}{l}\text { Lee, Roberts \& } \\
\text { Lau (1999) }\end{array}$ & $\begin{array}{l}\text { Questionnaire } \\
\text { survey }\end{array}$ & Hong Kong & $\begin{array}{l}\text { - Understanding of ISO standards and requirements } \\
\text { - The change of culture of the whole company due to } \\
\text { people resistance } \\
\text { - Lack of resources } \\
\text { - Staff competence }\end{array}$ \\
\hline $\begin{array}{l}\text { Lipovatz et al. } \\
(1999)\end{array}$ & $\begin{array}{l}\text { Questionnaire } \\
\text { survey }\end{array}$ & 111 Greek companies & $\begin{array}{l}\text { - Mentality change } \\
\text { - Mistrust of certification } \\
\text { - Avoiding responsibilities } \\
\text { - Bureaucracy of documentation } \\
\text { - Additional workload }\end{array}$ \\
\hline $\begin{array}{l}\text { Fuentes et al. } \\
(2000)\end{array}$ & $\begin{array}{l}\text { Questionnaire } \\
\text { survey }\end{array}$ & $\begin{array}{l}77 \text { certified companies } \\
22 \text { consultants in Spain }\end{array}$ & $\begin{array}{l}\text { - Difficulty of communicating new tasks and jobs } \\
\text { - Resistance to new responsibilities, } \\
\text { - Difficulty in cooperation, } \\
\text { - Lack of employee's involvement } \\
\text { - Lack of communication. }\end{array}$ \\
\hline $\begin{array}{l}\text { Glover \& Siu } \\
(2000)\end{array}$ & Case study & $\begin{array}{l}2 \text { case study } \\
\text { companies in china }\end{array}$ & $\begin{array}{l}\text { - Poor commitment and motivation of workers } \\
\text { - Low coordination and team work } \\
\text { - Avoidance of responsibility } \\
\text { - Lack of communication }\end{array}$ \\
\hline $\begin{array}{l}\text { Al-Khalifa \& } \\
\text { Aspinwall (2000) }\end{array}$ & $\begin{array}{l}\text { Questionnaire } \\
\text { survey }\end{array}$ & $\begin{array}{l}143 \text { organizations in } \\
\text { Qatar }\end{array}$ & $\begin{array}{l}\text { - Lack of training } \\
\text { - Top management support } \\
\text { - Human resources } \\
\text { - Financial resources } \\
\text { - Time }\end{array}$ \\
\hline $\begin{array}{l}\text { Zain \& Amar } \\
(2002)\end{array}$ & $\begin{array}{l}\text { Questionnaire } \\
\text { survey }\end{array}$ & $\begin{array}{l}78 \text { Organizations in } \\
\text { Indonesia }\end{array}$ & $\begin{array}{l}\text { - Issues related to human resources } \\
\text { - Top management commitment } \\
\text { - Organizational culture } \\
\text { - Weak interdepartemental relations }\end{array}$ \\
\hline $\begin{array}{l}\text { Curry \& Kadasah } \\
\text { (2002) }\end{array}$ & $\begin{array}{l}\text { Questionnaire } \\
\text { survey }\end{array}$ & $\begin{array}{l}83 \text { firms in Saoudi } \\
\text { Arabia }\end{array}$ & $\begin{array}{l}\text { - The need to change the existing system } \\
\text { - Resistance to change by employees } \\
\text { - Lack of understanding, of ISO implementing ISO } \\
9001\end{array}$ \\
\hline Sharif (2005) & $\begin{array}{l}\text { Questionnaire } \\
\text { survey }\end{array}$ & $\begin{array}{l}2 \text { case study companie } \\
\text { in Libya }\end{array}$ & $\begin{array}{l}\text { - Lack of understanding and knowledge of ISO } \\
\text { standard and QMS } \\
\text { - Costs of certification } \\
\text { - Lack of continuous training programs } \\
\text { - Lack of communication }\end{array}$ \\
\hline $\begin{array}{l}\text { Dale, Van der } \\
\text { Wiele \& Van } \\
\text { Iwaarden (2007) }\end{array}$ & & General & $\begin{array}{l}\text { - Inadequate leadership causing employees resistance } \\
\text { - Policies against QMS objectives } \\
\text { - Poor management of the change process }\end{array}$ \\
\hline
\end{tabular}




\begin{tabular}{|c|c|c|c|}
\hline Authors & Research method & Country and sample & Identified Barriers \\
\hline $\begin{array}{l}\text { Hesham \& Magd } \\
\text { (2007) }\end{array}$ & $\begin{array}{l}\text { Questionnaire } \\
\text { survey }\end{array}$ & 70 firms in Egypt & $\begin{array}{l}\text { - The need to change the existing system } \\
\text { - Resistance to the standard introduction } \\
\text { - Lack of understanding its importance } \\
\text { - Costs and time consumption }\end{array}$ \\
\hline $\begin{array}{l}\text { Bhat \& } \\
\text { Rajashekhar } \\
(2009)\end{array}$ & Questionnaire & $\begin{array}{l}41 \text { organizations in } \\
\text { India }\end{array}$ & $\begin{array}{l}\text { - Lack of customer orientation } \\
\text { - Lack of planning for quality } \\
\text { - Lack of total involvement } \\
\text { - Lack of management commitment } \\
\text { - Lack of resources }\end{array}$ \\
\hline $\begin{array}{l}\text { Burcher, Lee \& } \\
\text { Waddell (2010) }\end{array}$ & Questionnaire & $\begin{array}{l}129 \text { Australian and } 175 \\
\text { British companies }\end{array}$ & $\begin{array}{l}\text { Three main difficulties were identified for an } \\
\text { organization when implementing quality initiatives in } \\
\text { Australia: } \\
\text { - Communication } \\
\text { - Organizational inertia } \\
\text { - Commitment. } \\
\text { While in Britain, commitment was singled out as the } \\
\text { most significant factor }\end{array}$ \\
\hline $\begin{array}{l}\text { Kumar \& } \\
\text { Balakrishnan } \\
\text { (2011) }\end{array}$ & Questionnaire & $\begin{array}{l}100 \text { contractors from } \\
\text { UAE }\end{array}$ & $\begin{array}{l}\text { - Leadership related issues } \\
\text { - Strategy Related Issues } \\
\text { - Quality System related issues } \\
\text { - Society oriented gaps }\end{array}$ \\
\hline $\begin{array}{l}\text { Al-Najjar \& } \\
\text { Jawad (2011) }\end{array}$ & $\begin{array}{l}\text { Questionnaire } \\
\text { survey }\end{array}$ & 42 companies in Iraq & $\begin{array}{l}\text { - Top management commitment } \\
\text { - employee resistance } \\
\text { - Difficulty of performing internal audits } \\
\text { - Requirements of the standards are unrealistic }\end{array}$ \\
\hline Khan (2011) & $\begin{array}{l}\text { Questionnaire } \\
\text { survey }\end{array}$ & $\begin{array}{l}120 \text { quality managers } \\
\text { in pakistan }\end{array}$ & $\begin{array}{l}\text { - Lack of planning } \\
\text { - Lack of efficient human resources practices } \\
\text { - Inadequate infrastructure } \\
\text { - Lack of support from leadership } \\
\text { - Lack of customer focus }\end{array}$ \\
\hline Willar (2012) & $\begin{array}{l}\text { Questionnaire } \\
\text { survey }\end{array}$ & $\begin{array}{l}77 \text { companies in } \\
\text { Indonesia }\end{array}$ & $\begin{array}{l}\text { - ISO } 9001 \text { being a matter of fulfilling audit } \\
\text { requirements } \\
\text { - Misleading QMS purposes } \\
\text { - Lack of a well-design reward system }\end{array}$ \\
\hline $\begin{array}{l}\text { Mosadeghrad } \\
\text { (2014) }\end{array}$ & Literature review & $\begin{array}{l}54 \text { empirical studies } \\
\text { wordwide }\end{array}$ & $\begin{array}{l}\text { - Insufficient education and training } \\
\text { - Lack of employees' involvement } \\
\text { - Lack of top management support } \\
\text { - Inadequate resources } \\
\text { - Deficient leadership } \\
\text { - Lack of a quality-oriented culture } \\
\text { - Poor communication } \\
\text { - Lack of a plan for change } \\
\text { - Employee resistance }\end{array}$ \\
\hline $\begin{array}{l}\text { Jayasundara \& } \\
\text { Rajini } \\
(2014)\end{array}$ & $\begin{array}{l}\text { Questionnaire } \\
\text { survey }\end{array}$ & $\begin{array}{l}10 \text { ISO } 9001 \text { well } \\
\text { experienced } \\
\text { professionals, in Sri } \\
\text { lanka }\end{array}$ & $\begin{array}{l}\text { - Lack of top management involvement during the } \\
\text { implementation process' } \\
\text { - Unwillingness of employees to change work systems } \\
\text { - Weak interdepartmental relations } \\
\text { - Employee resistance }\end{array}$ \\
\hline $\begin{array}{l}\text { Talib \& Rahman } \\
\text { (2015) }\end{array}$ & Literature review & General & $\begin{array}{l}\text { - Lack of communication } \\
\text { - Lack of top-management commitment } \\
\text { - Employee's resistance to change } \\
\text { - Lack of coordination between departments }\end{array}$ \\
\hline
\end{tabular}

Table 1. Systematic review 
From Table 1 there is literature to support the following points:

- The shortage of Arabic studies, not one on those studies was carried out in Moroccan organizations. This supports the originality of this research and adds another contribution to the field;

- Most common barriers in studies mentioned in Table 1 are: Top management related issues (lack of commitment and inadequate leadership), resistance of employees and lack of resources;

- All Arabic countries mentioned in Table 1 experienced human resources barriers to QMS implementation such as issues related to understanding the purpose of ISO 9001 certification, requirements of the standard in additon to lack of competence in the field.

Despite all the barriers found in the literature quality management's benefits are no longer a secret, according to Fonseca, Domingues, Machado and Calderón (2017), a systematic review of articles published since 1996 shows that the Management Systems adoption and certification bring fairly positive benefits (average 2,34 in a 1 to 5 Likert type scale) for the certified organizations.

Managing quality leads to tangible benefits such as the reduction of non-quality costs and non-added value activities and processes in addition to intangible benefits as for instance, increased customer satisfaction, maximized workforce motivation and improved environmental impact. (Knowles, 2011)

Organizations are seeking ISO 9001 certification for other reasons such as costumer pressure, efficiency and competitiveness maximization, business performance, corporate image and prestige (Lipovatz et al., 1999; Ismail-Salaheldin, 2003; Beck \& Walgenbach, 2003; Martínez-Costa, Martínez-Lorente \& Choi, 2008; Almeida, Caten \& Gutterres, 2009; Cagnazzo, Taticchi \& Fuiano, 2010; Al-Refaie, Ghnaimat \& Li, 2012; McCrosson, Cano, O’Neill \& Kobi, 2013).

\section{Research Methodology}

To explore the critical obstacles associated with ISO 9001 implementation in Morocco, an explorative questionnaire survey was conducted among a sample of 200 certified companies, heterogeneous in sizes, locations and sectors. The questionnaire was created and distributed online to facilitate responses collection.

The survey process began on 1 April 2015 and answers were accepted until 30 April 2016. 115 responses were received (response rate of 57,5), a total of 94 responses were usable. The research tool was created after an extensive literature review on barriers to quality management in general, and difficulties in ISO 9001 implementation in particular. It was pilot tested with quality consultants and managers, then variables were approved and the form was refined to develop the final questionnaire. The questionnaire was addressed to Quality Managers.

The questionnaire was divided to three sections (Annex A), the first was dedicated to information about the organization and the respondent. As for the second section, there were questions related to the actual implementation, role of consultancy, QMS documentation and the reasons behind seeking ISO 9001 certification. While the third and final section was about 32 barriers to implementation, a Likert scale was used for this section (Strongly agree, Agree, Disagree, strongly disagree or Non-applicable/not sure). A numerical transformation enabled the adoption of statistical analysis of data. The statistical analysis is based on participants' level of agreement with each statement on a scale of $1=$ strongly disagree to $4=$ strongly agree.

Figure 3 below presents the research structure with expected outcomes of different phases. 


\section{Phase 1}

Objectives: Identify barriers to quality initiatives in general and ISO 9001 implementation in international contexts

Research method: Literature review

Phase 2

Objectives: Develop a draft research instrument

Research method: Literature review

Expected outcomes

Theoretical framework

Expected outcomes

Draft questionnaire and variables

\section{Phase 3}

Objectives: Confirm selected variables and shape the final questionnaire with necessary modifications based on information developed in phase 2

Research method: Pilot study, qualitative

Phase 4

Objectives: Identification of problems faced during the implementation of ISO 9001 in Moroccan organizations

Research method: Questionnaire, quantitative

\section{Expected outcomes}

Final questionnaire

Figure 3. Research structure

\section{Findings}

\subsection{Surveyed Companies Profile}

Table 2 below shows the characteristics of the companies surveyed. Services companies represent $17.02 \%$ of the sample, while manufacturing companies are $82.7 \%$. Small companies represent $56.38 \%$ of the total sample.

\begin{tabular}{|l|l|r|r|}
\hline \multirow{4}{*}{ n } & \multicolumn{1}{|c|}{$\%$} \\
\hline \multirow{4}{*}{ Number of employees } & Micro & 13 & 13.83 \\
\cline { 2 - 4 } & Small & 53 & 56.38 \\
\cline { 2 - 4 } & Medium & 21 & 22.34 \\
\cline { 2 - 4 } & Large & 7 & 7.45 \\
\hline \multirow{3}{*}{ Typology } & Manufacturing companies & 78 & 82.98 \\
\hline \multirow{3}{*}{ External consutancy } & Service companies & 16 & 17.02 \\
\cline { 2 - 4 } & Yes & 63 & 67.02 \\
\cline { 2 - 4 } & No & 31 & 32.97 \\
\hline
\end{tabular}

Table 2. Characteristics of surveyed companies $(n=94)$ 
Figure 4 shows the years of certification of surveyed companies in relation to their size; most of the companies (from 52,38\% up) are certified between two and seven years.

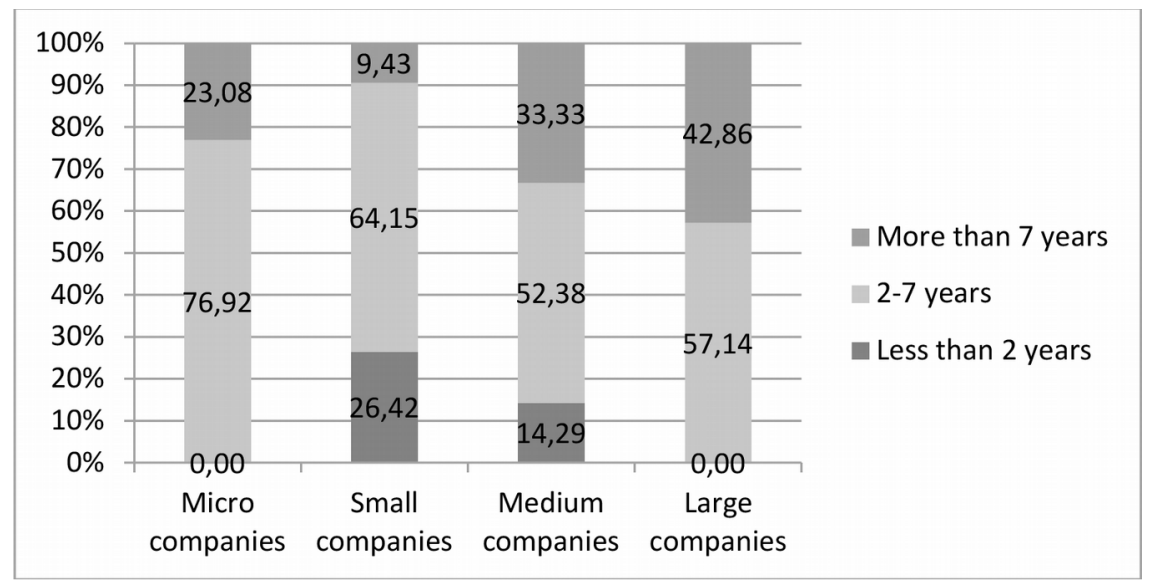

Figure 4. Years of ISO 9001:2008 certification of surveyed companies

\subsection{Reasons of Certification}

ISO 9001 motivations and benefits can be categorized as being mostly external or internal ones. External reasons are essentially related with marketing and promotional issues, while the internal category is related to internal organizational improvements. According to the literature, companies maximize their benefits if they achieve ISO 9001 certification based on internal motivations. (Sampaio, Saraiva \& Rodrigues, 2009)

When respondents were asked about reasons to seek certification which was a multiple-choice question, ranking of reasons came as indicated below (Figure 5):

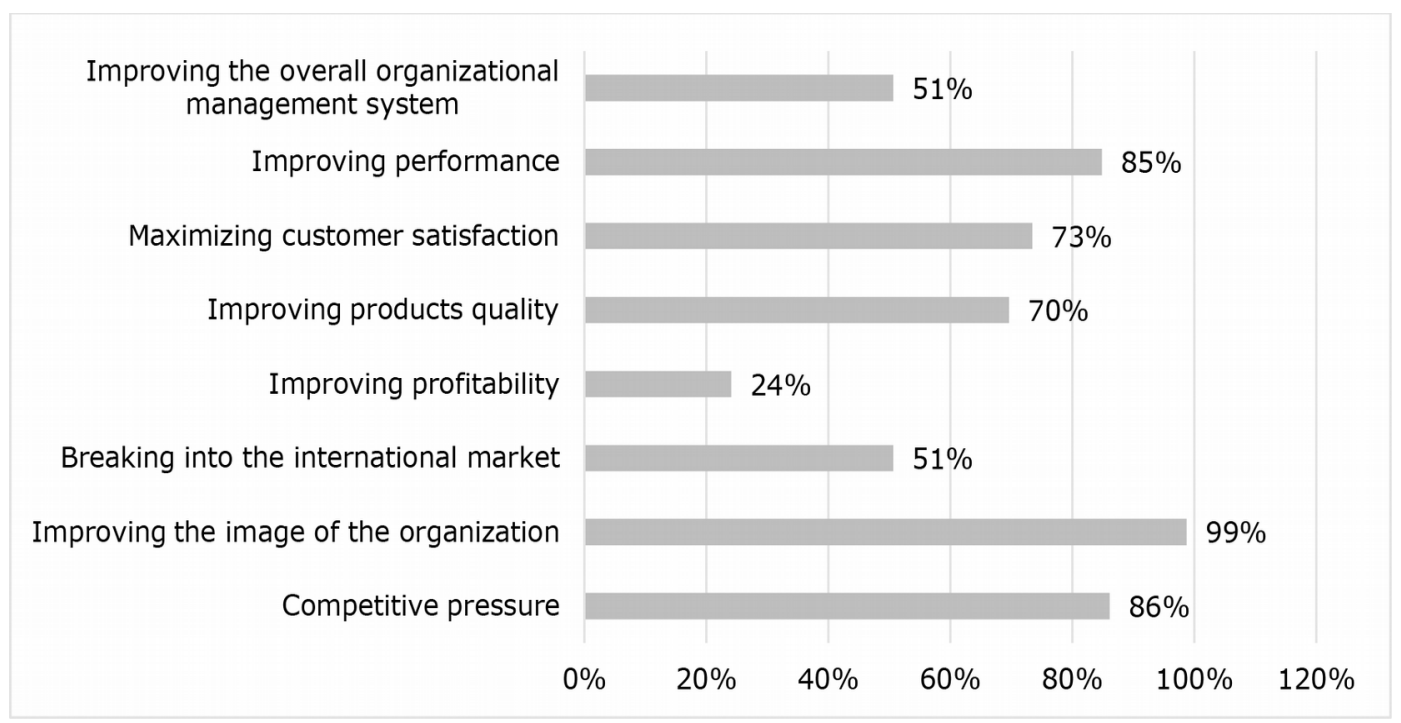

Figure 5. Responses on reasons for ISO implementation in Moroccan organizations

A high percentage of respondents approved that the improvement of the organization's image and competitive pressure are important factors behind seeking ISO 9001 certification. Internal improvement reasons came second such as performance, product's quality and customer satisfaction improvement. In Georgiev and Georgiev (2015) same reasons were dominant as enhanced company image and competitiveness was reported to be the leading motivational factor for ISO 9001 certification in Bulgaria. Al-Khalifa and Aspinwall (2000), Sharif (2005) and Cagnazzo et al. (2010), also cited that certification was mainly a marketing and advertising tool to companies to improve their image and prestige. 


\subsection{Barriers to ISO 9001:2008 Implementation}

Regarding impeding factors to ISO 9001 implementation in Moroccan organizations, most important barriers $(\mathrm{m}>2,5)$ according to respondent's opinion are shown in (Table 3) below: (The least important barriers are presented in Annex B)

\begin{tabular}{|c|c|c|c|}
\hline Barriers & Mean & SD & Ranking \\
\hline Resistance to change & 3.479 & 0.699 & 1 \\
\hline Poor interdependance between departements & 3.064 & 0.981 & 2 \\
\hline Lack of top management commitment & 3.043 & 1.135 & 3 \\
\hline Dominance of bureaucracy & 2.947 & 1.030 & 4 \\
\hline $\begin{array}{l}\text { Lack of internal communication among staff and between staff } \\
\text { and top management }\end{array}$ & 2.840 & 0.965 & 5 \\
\hline Insufficiant requirements diffusion to all organizational levels & 2.798 & 0.886 & 6 \\
\hline Lack of trainings & 2.796 & 0.950 & 7 \\
\hline Difficulty in changing culture & 2.777 & 1.069 & 8 \\
\hline Difficulty in process identification and management & 2.630 & 1.096 & 9 \\
\hline
\end{tabular}

Table 3. Barriers to ISO 9001 implementation according to respondents

All hindrances are organizational except the fifth and sixth factors which are technical issues related to communication. These findings are consistent with studies mentioned in the literature review. The most significant obstacle is resistance to change. Resistance is an expected barrier to organizational change as mentioned by Gill (2003). Employee may misunderstand the benefits of change and avoid it in every possible way, he may fear lack of competence, failure at changing the old way of doing things, or assuming new responsibilities other than his current tasks. Same barrier was pointed out by Lee et al (1999), Fuentes et al. (2000), Curry and Kadasah (2002), Hesham and Magd (2007), Al-Najjar and Jawad (2011) and Talib and Rahman (2015). This can be prevented with raising awareness about benefits of implementation and removing misconceptions about quality initiatives, organization should invite employees to participate in the change process rather than oblige them to undergo change, in addition, trainings are important to make employees more secure in their new responsibilities and readier to do things differently.

The second important barrier is lack of interdependence between departments. Zain and Amar (2002), Jayasundara and Rajini (2014) and Talib and Rahman (2015) also found that poor interdepartmental relations are a great impedance to quality management. This barrier brings into question the degree of incorporation of the process approach in the organization. Despite the process approach being one of the eight principals of ISO 9001, respondents found that Moroccan organizations are still suffering from isolated departments. Companies tend to consider procedures and processes as documented information instead of a way of functioning. Organizations have to operate as a set of interrelated processes instead of isolated departments in order to have a successful quality management system, the process approach provide the solution if implemented right.

Another obstacle is top management commitment which is an essential factor in quality management programs. Respondents who filled the comment section related to this barrier, mentioned that top management is preoccupied by short term goals, profitability and quantity instead of quality and, in addition, nearly all of quality related responsibilities are fulfilled by the quality manager. This finding is assisted by other studies such as Masters (1996), Al-Khalifa and Aspinwall (2000), Burcher et al. (2010) and Bhat and Rajashekhar (2009). Top managers must clearly understand the linkage between financial performance, profitability and the quality management system in order to increase their engagement and commitment in the ISO 9001 implementation. 
Dominance of bureaucratic thinking and the difficulty of changing culture are also ascertained to be important inhibiting factors to ISO 9001 implementation. In order to be costumer focused and achieve quality, every level of the organization should participate in the journey of pursuing it regardless their position or job within the company. Every person working in the organization matters, every job and every responsibility is important, everyone is part of the team. To have a successful quality management, customer satisfaction should be everybody's goal, all employees have to participate in related missions, solving related problems and managers must empower them to participate in quality management regardless their status within the organization. Changing culture is difficult because many organizations are rigid and lack dynamism in the way of doing things, however bureaucratic culture should be gradually changed into an adhocratic thinking in order to ensure quality management efficiency.

In addition, Respondents believed that lack of internal communication is a barrier to implementation, Fuentes et al. (2000), Glover and Siu (2000), Sharif (2005), Burcher et al. (2010) and Talib and Rahman (2015) also agreed on poor communication being a significant barrier to managing quality. Main reasons to this barrier are gaps between employees, middle and top management, and lack of coordination between departments. Insufficient diffusion of requirements to all organizational levels is also an issue, this can lead to employee's unawareness of responsibilities regarding quality, this also emphasizes bureaucratic thinking rather than participative approach to manage quality and achieve customer satisfaction.

Another barrier is the lack of training that leads to poor competence in fulfilling tasks related to the quality management system such as experiencing difficulties in process identification and management which is the final important barrier to ISO 9001 implementation according to respondents.

\subsection{External Consultancy}

Figure 6 shows results of responses on reasons to implementation based on whether or not organizations sought external consultancy

On another hand, results of the study indicated that companies who sought use of external consultancy (67\%) chose more the ISO 9001 implementation for market related reasons than organizations that chose to go through the implementation process without consultancy.

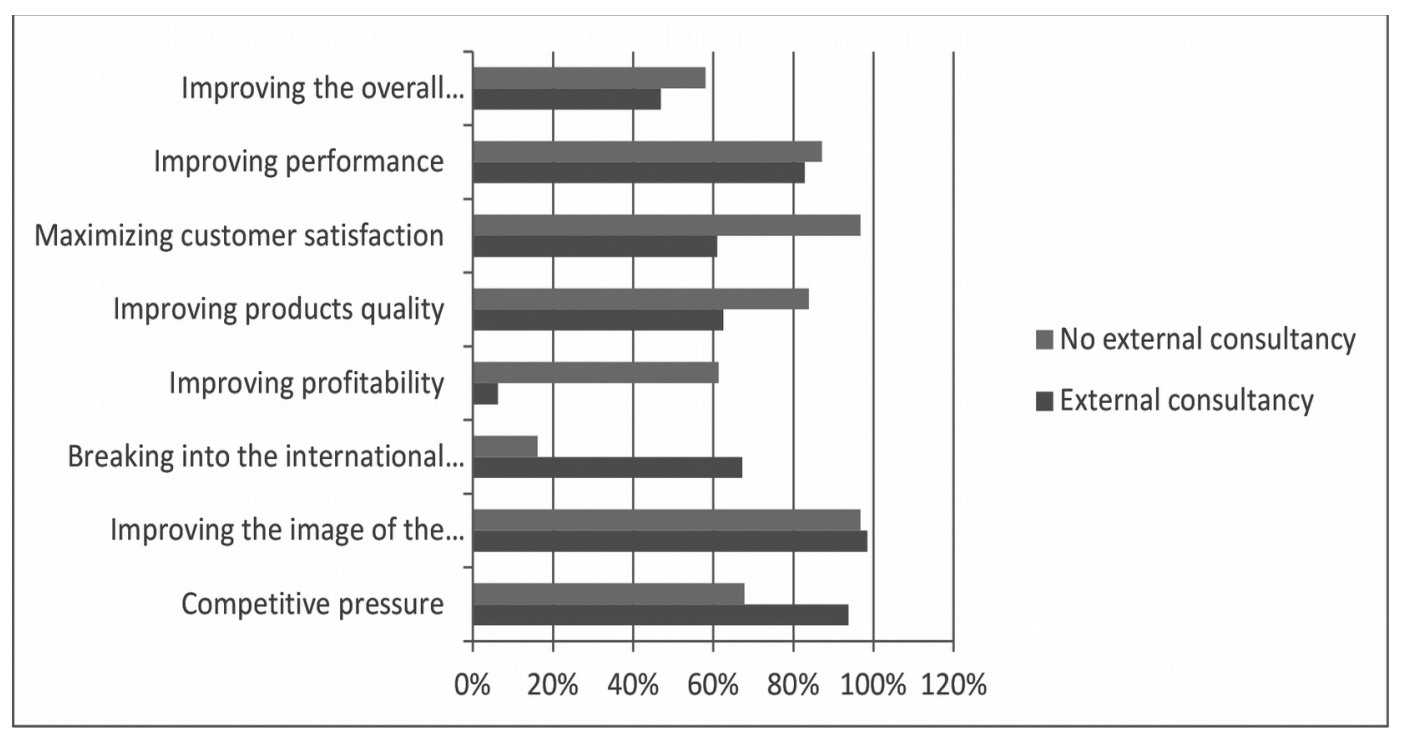

Figure 6. Responses on reasons for ISO implementation in Moroccan organizations based on external consultancy

As Table 4 shows the results of $\mathrm{t}$ test on most important barriers in organizations based on external consultancy, organizations who used external consultants experienced more lack of training and lack of communication and requirements diffusion $(|t|>C$ value, $\alpha=0.05)$. 
Lack of trainings can be explained as staff and managers' competence did not seem to matter to the organization as the implementation process was ensured by external consultants. Communication and requirements diffusion to all levels of organizations also were not obviously a preoccupancy to consultants who neglected employee involvement and participation in the implementation process or the organization avoided it to minimize time of the implementation and financial resources consumption by trainings of staff and managers. Therefore, lack of trainings and communication results in increased bureaucracy and furthermore, more resistance from the workforce. Similar findings were reported by Carlsson and Carlsson (1996) and Lipovatz et al. (1999) concerning Swedish and Greek companies. In addition, 26\% among organizations who were assisted in the implementation process, the quality management system documentation was exclusively elaborated by the external consultants, and $53 \%$ by both quality managers and external consultants. The problem is the unfamiliarity of external consultants with internal organizational processes, procedures and culture, which can result in unsuitable quality management systems to companies. To remedy this problem, using both well trained internal consultants and competent external advisors can make organizations benefit on one hand, from a best understanding of current organizational policies, processes and culture and on the other hand, from a best objectivity and a better understanding of the standard and industry best practices.

\begin{tabular}{|c|c|c|c|c|c|c|}
\hline & \multirow{2}{*}{\multicolumn{2}{|c|}{$\begin{array}{l}\text { No external consultancy } \\
\qquad(\mathrm{n}=31)\end{array}$}} & \multirow{2}{*}{\multicolumn{2}{|c|}{$\begin{array}{l}\text { External consultancy } \\
\qquad(\mathrm{n}=63)\end{array}$}} & \multirow[b]{3}{*}{$\mathrm{t}$ test } & \multirow[b]{3}{*}{$\mathrm{C}$ value } \\
\hline & & & & & & \\
\hline & Mean & Sd & Mean & Sd & & \\
\hline Resistance to change & 3.419 & 0.672 & 3.508 & 0.716 & -0.5882 & 1.671 \\
\hline $\begin{array}{l}\text { Poor interdependance } \\
\text { between departements }\end{array}$ & 3.065 & 1.031 & 3.048 & 0.991 & 0.0757 & 1.676 \\
\hline $\begin{array}{l}\text { Lack of top management } \\
\text { commitment }\end{array}$ & 3.129 & 1.118 & 3.000 & 1.150 & 0.5211 & 1.671 \\
\hline Dominance of bureaucracy & 3.000 & 1.000 & 2.921 & 1.052 & 0.3556 & 1.671 \\
\hline $\begin{array}{l}\text { Lack of internal } \\
\text { communication among staff } \\
\text { and between staff and top } \\
\text { management }\end{array}$ & 2.484 & 1.122 & 3.016 & 0.833 & -2.3426 & 1.679 \\
\hline $\begin{array}{l}\text { Insufficiant requirements } \\
\text { diffusion to all organizational } \\
\text { levels }\end{array}$ & 2.355 & 0.839 & 3.016 & 0.833 & -3.6024 & 1.676 \\
\hline Lack of trainings & 2.452 & 0.995 & 2.968 & 0.630 & -2.445 & 1.676 \\
\hline Difficulty in changing culture & 2.968 & 1.080 & 2.683 & 1.072 & 1.3216 & 1.676 \\
\hline $\begin{array}{l}\text { Difficulty in process } \\
\text { identification and } \\
\text { management }\end{array}$ & 2.690 & 1.039 & 2603 & 1.129 & 0.3608 & 1.676 \\
\hline
\end{tabular}

Table 4. $t$ test applied Important barriers of ISO 9001:2008 implementation based on external consultancy

\section{Expectations on ISO 9001:2015 Implementation in Moroccan Organizations}

Organizations should not be concerned that ISO 9001:2015 will be a major source of problems. It will have major benefits for Quality Management Systems with less emphasis on documentation and new/reinforced approaches like consideration of organizational context and relevant interested parties and risk based thinking for the establishment, implementation, maintenance and continual improvement of the quality management system. (Fonseca, 2016)

Authors believe that these changes brought by the new standard will help reduce barriers to ISO 9001 implementation in Moroccan organizations, experienced with the previous version of the standard.

Table 5 below indicates expected influence of new requirements of 2015 revision of ISO 9001 standard on barriers to ISO 9001:2008 in Moroccan organizations. 


\begin{tabular}{|c|c|c|c|}
\hline Barriers & Chapter/Clause & Requirement & Expectations \\
\hline Resistance to change & $\begin{array}{l}\text { Clause } 4.2 \text {. } \\
\text { Understanding the needs } \\
\text { and expectations of } \\
\text { interested parties }\end{array}$ & $\begin{array}{l}\text { Determination of the interested } \\
\text { parties that are relevant to the } \\
\text { environmental management } \\
\text { system and their relevant needs } \\
\text { and expectations. }\end{array}$ & $\begin{array}{l}\text { Understanding and defining needs } \\
\text { and expectations of people } \\
\text { working within organizations as } \\
\text { stakeholders can increase job } \\
\text { satisfaction, motivation to be fully } \\
\text { engaged in the change process and } \\
\text { prevent resistance. }\end{array}$ \\
\hline $\begin{array}{l}\text { Lack of top } \\
\text { management } \\
\text { commitment }\end{array}$ & $\begin{array}{l}\text { Chapter } 5 . \\
\text { Leadership }\end{array}$ & $\begin{array}{l}\text { Demonstration of leadership and } \\
\text { providing evidence of } \\
\text { commitment to the development, } \\
\text { implementation and improvement } \\
\text { of the QMS. }\end{array}$ & $\begin{array}{l}\text { Increasing top management } \\
\text { commitment }\end{array}$ \\
\hline $\begin{array}{l}\text { Difficulty in process } \\
\text { identification and } \\
\text { management }\end{array}$ & \multirow{2}{*}{$\begin{array}{l}\text { Clause 7.1.6. } \\
\text { Organizational } \\
\text { Knowledge }\end{array}$} & \multirow{2}{*}{$\begin{array}{l}\text { Determination of the knowledge } \\
\text { necessary for the operation of its } \\
\text { processes and to achieve } \\
\text { conformity of products and } \\
\text { services. } \\
\text { This knowledge shall be } \\
\text { maintained and made available to } \\
\text { the extent necessary. }\end{array}$} & \multirow{2}{*}{$\begin{array}{l}\text { Establishing knowledge and } \\
\text { competence goals at the start of } \\
\text { the implementation process and } \\
\text { planning to achieve an effective } \\
\text { QMS by means of trainings and } \\
\text { learning on the standard. }\end{array}$} \\
\hline Lack of trainings & & & \\
\hline All barriers & $\begin{array}{l}\text { Clause } 4.1 . \\
\text { Internal \& External } \\
\text { Issues }\end{array}$ & $\begin{array}{l}\text { The organization shall determine } \\
\text { external and internal issues that } \\
\text { affect its ability to achieve the } \\
\text { intended results of its quality } \\
\text { management system. }\end{array}$ & $\begin{array}{l}\text { Managing these barriers as risk } \\
\text { sources affecting performance and } \\
\text { results in terms of quality } \\
\text { management }\end{array}$ \\
\hline
\end{tabular}

Table 5. Expectations on the impact of ISO 9001:2015 requirements on barriers to the previous version in Moroccan organizations

\section{Conclusion}

When change is brought into an organization, many barriers acting against its introduction arise. ISO 9001 implementation does not make an exception as organizations around the world experience difficulties during the implementation process.

This study was the first of its kind to be conducted in Morocco, a questionnaire survey explored barriers to ISO 9001 implementation among 115 organizations operating in different sectors, to help Moroccan organizations particularly, and Arab organizations in general willing to get ISO 9001 certification to prepare themselves properly to overcome obstacles that are likely to occur during the change process. Findings validated earlier studies on reasons behind certification and barriers to quality initiatives.

Regarding reasons to implement a quality management system, market related reasons came first such as improving organization image and competitive pressure followed by internal improvement and customer satisfaction maximization. According to respondents, most impeding factors were organizational such as resistance to change, poor interdepartmental relations, difficulty of changing bureaucratic culture which was prominent within organizations according to respondents. Lack of top management commitment, communication and training were also an issue during the implementation process.

Managerial awareness of these obstacles is crucial to prevent these difficulties from occurring. An adequate management of the change process, efficient trainings, effective communication and high awareness about ISO 9001 benefits are highly recommended in order to ensure a successful implementation and increase the quality management system performance.

Further studies will be conducted to analyse ISO 9001:2015 applications and the impact of the new version on barriers experienced to the previous edition of the standard.

Findings of this paper provide Moroccan managers with a practical understanding of the factors that are likely to occur while implementing an ISO 9001 QMS, identifying these issues will enables Moroccan managers to develop 
strategies in order to ensure a successful implementation and therefore an effective QMS. Although this article focuses only on Moroccan organizations, its findings could be extrapolated to other geographic contexts especially Arab speaking countries as literature showed various similarities in barriers to QMS implementation in the Arab world.

\section{Acknowledgments}

The authors are thankful to all the responding quality managers in particular and all participating organizations in general for their great collaboration.

\section{Declaration of Conflicting Interests}

The authors declared no potential conflicts of interest with respect to the research, authorship, and/or publication of this article.

\section{Funding}

The authors received no financial support for the research, authorship, and/or publication of this article.

\section{References}

Ackerman-Anderson, L., \& Anderson D. (2010). The change leader road map How to navigate your organization's transformation. San Francisco: Pfeiffer.

Akdeniz, C. (2014). Change management explained. Germany: First publishing.

Al-Khalifa, A.K.N., \& Aspinwall, E.M. (2000). The development of total quality management in Qatar. The TQM Magazine, 12(3),194-204. https://doi.org/10.1108/09544780010320250

Al-Najjar, S.M., \& Jawad, M.K. (2011). ISO 9001 Implementation Barriers and Misconceptions: An Empirical Study. International Journal of Business Administration, 2(3), 118-131. https://doi.org/10.5430/ijba.v2n3p118

Almeida, M., Caten, C., \& Gutterres, M. (2009). Evaluating ISO 9001:2000 Certified and Non-Certified Organizations in Brazilian Leather-Footwear Chain. Brazilian Journal of Operations \& Production Management, 6(2), $51-73$.

Al-Refaie, A., Ghnaimat, O., \& Li, M. (2012). Effects of ISO 9001 Certification and KAAE on Performance of Jordanian Firms. Jordan Journal of Mechanical and Industrial Engineering, 6(1), 45-53.

Beck, N., \& Walgenbach, P. (2003). ISO 9000 And Formalization-How Organizational Contingencies Affect Organizational Responses to Institutional Forces. Schmalenbach Business Review, 55(4), 293-320. https://doi.org/10.1007/BF03396680

Bhat, K.S., \& Rajashekhar, J. (2009). An empirical study of barriers to TQM implementation in Indian industries. The TQM Magazine, 21(3), 261-272. https://doi.org/10.1108/17542730910953031

Burcher, P.G., Lee, G.L., \& Waddell, D. (2010). Quality lives on: quality initiatives and practices in Australia and Britain. The TQM Journal, 22 (5), 487-498. https://doi.org/10.1108/17542731011072838

Cagnazzo, L., Taticchi, P., \& Fuiano, F. (2010). Benefits, barriers and pitfalls coming from the ISO 9000 Implementation: the impact on business performances. WSEAS Transactions on Business and Economics, 7(4), 311-321.

Carlsson, M., \& Carlsson, D. (1996). Experiences of implementing ISO 9000 in Swedish industry. International Journal of Quality \& Reliability Management, 13(7), 36-47. https://doi.org/10.1108/02656719610128547 
Chiarini, A. (2017). Risk-based thinking according to ISO 9001:2015 standard and the risk sources European manufacturing SMEs intend to manage. The TQM Journal, 29 (2), 310-323. https://doi.org/10.1108/TQM-04-20160038

Curry, A., \& Kadasah, N. (2002). The yin and yang of quality systems evaluation. Managerial Auditing Journal, 17(7), 424-429. https://doi.org/10.1108/02686900210437543

Dale, B.G., Van der Wiele, T., \& Van Iwaarden, J. (2007). Managing quality. Victoria: Blackwell Publishing

Erdal, E., \& Ghosh, J. B. (1997). ISO 9000 Implementation in Turkish Industry. International Journal of Operations and Production Management, 17(12), 1233-1246. https://doi.org/10.1108/01443579710182972

Fonseca, L. (2015). Relationship between ISO 9001 certification maturity and EFQM business excellence model results. Quality Innovation Prosperity, 19(1), 85-102. https://doi.org/10.12776/qip.v19i1.556

Fonseca, L (2016). FROM quality gurus and TQM to ISO 9001:2015: A review of several quality paths. International Journal for Quality Research, 9, 167-180.

Fonseca, L.M., \& Domingues, J.P. (2017). Listen to ISO 9001:2015 for organizational competitiveness: Correlation between change management and improvement (916-926). In proceedings of the 11th International Conference on Business Excellence. https://doi.org/10.1515/picbe-2017-0097

Fonseca, L.M., Domingues, J.P., Machado, P.B., \& Calderón, M. (2017). Management system certification benefits: Where do we stand? Journal of Industrial Engineering and Management, 10(3), 476-494.

https://doi.org/10.3926/jiem.2350

Fuentes, M.C., Benavent, B.F., Moreno, M., Cruz, G.T., \& Pardo del Val, M. (2000). Analysis of the implementation of ISO 9000 quality assurance systems. Work Study, 49(6), 229-241. https://doi.org/10.1108/00438020010343408

Georgiev, S., \& Georgiev, E. (2015). Motivational factors for the adoption of ISO 9001 standards in Eastern Europe: the case of Bulgaria. Journal of Industrial Engineering and Management, 8(3), 1020-1050. https://doi.org/10.3926/jiem.1355

Gill, R. (2003). Change management - or change leadership? Journal of Change Management, 3(4), 307. https://doi.org/10.1080/714023845

Glover, L., \& Siu, N. (2000). The human resource barriers to managing quality in China. The International Journal of Human Resource Management, 11(5), 867-882. https://doi.org/10.1080/095851900422320

Hesham, A., \& Magd, E. (2007). ISO 9001:2000 Certification Experiences in Egyptian Manufacturing Sector: Perceptions and Perspectives. International Journal of Quality \& Reliability Management, 25(2), 173-200. https://doi.org/10.1108/02656710810846934

Hiatt, J., \& Creasey, T.J. (2012). Change Management: The People Side of Change, USA: Prosci Learning Center Publications

International Organization of Standardisation (ISO) (2015). ISO 9001 survey 2015. Available at: http://www.iso.org/iso/iso 9001 iso survey2015.xls (Accessed: November 2016).

Ismail-Salaheldin, S. (2003). The implementation of TQM strategy in Egypt: A field-force analysis. The TQM Magazine, 15(4),266-274. https://doi.org/10.1108/09544780310486173

Jayasundara, A.J.M.D.C., \& Rajini, P.A.D. (2014). Enablers and barriers of implementing ISO 9001 Quality management system in the service sector in Sri lanka (vol. 18, abstract 896). Proceedings of the Peradeniya Univ. International Research Sessions. Sri Lanka.

Khan, M.A. (2011). An empirical study in implementing total quality management in service organizations in Pakistan. Asian journal of business management studies, 2(4), 155-161.

Knowles, G. (2011). Quality management. Denmark: Ventus Publishing ApS.

Kumar, D.A., \& Balakrishnan, V. (2011). A study on ISO 9001 quality management system (QMS) certifications reasons behind the failure of ISO certified organizations. Journal of Research in International Business and Management, $1(6), 147-154$. 
Lee, S.F., Roberts, P., \& Lau, W.S. (1999). Survey on ISO 9000 quality management system implementation in Hong Kong. Managerial Auditing Journal, 14(1/2), 79-88. https://doi.org/10.1108/02686909910245793

Lipovatz, D., Stenos, F., \& Vaka, A. (1999). Implementation of ISO 9000 quality systems in Greek enterprises. International Journal of Quality and Reliability Management, 16(6), 534-551. https://doi.org/10.1108/02656719910278575

Martínez-Costa, M., Martínez-Lorente, A., \& Choi, T. (2008). Simultaneous consideration of TQM and ISO 9000 on performance and motivation: An empirical study of Spanish companies. International Journal of Production Economics, 113(1), 23-39. https://doi.org/10.1016/j.ijpe.2007.02.046

Masters, R.J. (1996). Overcoming barriers to TQM's success. Quality progress, 29(5), 53-55.

McCrosson, S., Cano, M., O’Neill, E., \& Kobi, A. (2013). ISO 9001 Certification in UK Organisations. A comparative study of motivations and impacts. Unpublished manuscript, QUALITA 2013, Compiègne, France. Available at: https://hal.archives-ouvertes.fr/hal-00823149/document

Mo, J.P.T., \& Chan, A.M.S. (1997). Strategy for the successful implementation of ISO 9000 in small and medium manufacturers. The TQM Magazine, 9(2),135-145. https://doi.org/10.1108/09544789710165581

Mosadeghrad, A.M. (2014). Factors influencing healthcare service quality. International Journal of Health Policy and Management, 3(2), 77-89. https://doi.org/10.15171/ijhpm.2014.65

Ngai E.W.T., \& Cheng, T.C.E. (1997). Identifying potential barriers to total quality management using principal component analysis and correspondenceanalysis. International Journal of Quality \& Reliability Management, 14(4), 391-408. https://doi.org/10.1108/02656719710170657

Paton, R.A., \& McCalman, J. (2008). Change management A guide to effective implementation. London: SAGE Publications Ltd.

Rybski. C., Jochem. R., \& Homma, L. (2017). Empirical study on status of preparation for ISO 9001:2015. Total Quality Management \&o Business Excellence, 28(9-10), 1076-1089. https://doi.org/10.1080/14783363.2017.1303886

Sampaio. P, Saraiva. P, \& Rodrigues. A.G. (2009). ISO 9001 certification research: Questions, answers and approaches. International Journal of Quality \& Reliability Management, 26(1), 38-58.

https://doi.org/10.1108/02656710910924161

Sharif, I.M. (2005). The Barriers Affecting the Implementation of Quality Management System-ISO 9000 in Libyan Manufacturing Public Sector Organisations. PhD Thesis. Faculty of Business and Informatics University of Salford, UK. Available at: http://usir.salford.ac.uk/14870/1/DX232487.pdf

Singhal, D., \& Singhal, K.R. (2012). Implementing ISO 9001:2008 quality management system A reference guide, New delhi: PHI Learning Private Limited.

Talib, F., \& Rahman, Z. (2015). Identification and prioritization of barriers to total quality management implementation in service industry: an analytic hierarchy process approach. The TQM Journal, 27(5), 591-615. https://doi.org/10.1108/TQM-11-2013-0122

Tricker, R. (2016). ISO 9001:2015 in Brief. New York: Routledge.

Willar, D. (2012). Improving quality management system implementation in indonesian construction companies. PhD Thesis. Queensland University of Technology, Indonesia. Available http://eprints.qut.edu.au/59202/1/Debby Willar Thesis.pdf

Zain, Z.M., \& Amar, K. (2002). Barriers to implementing TQM in Indonesian manufacturing industries. The Magazine, 14 (6), 367-372. https://doi.org/10.1108/09544780210447474

Zairi, M. \& Youssef, M.A. (1995). Benchmarking critical factors for TQM. Benchmarking for Quality Management \& Technology, 2(2), 3-19. https:// doi.org/10.1108/14635779510081616

Zorn, T., Christensen, L.T., \& Cheney, G. (1999). Do We Really Want Constant Change?: Beyond the Bottom Line. San Fransisco: Berrett-Koehler-Publishers. 


\section{Annex A: Questionnaire}

\section{Questionnaire}

Please answer the following questions by checking $(\mathrm{x})$ the appropriate box or writing your answer in the space provided. Questions with $\left(^{*}\right)$ are mandatory.

\section{Informations on the respondent}

Respondent:

Organization*:

Organization size*:

\begin{tabular}{|l|l|}
\hline Largue & Sedium \\
\hline
\end{tabular}

Organization sector*:

\begin{tabular}{|c|}
\hline Service \\
\hline
\end{tabular}

What is your job within the organization:

\begin{tabular}{|c|}
\hline Quality manager \\
Other \\
\hline
\end{tabular}

For how long has the organization been ISO 9001 certified?*

$$
2>\text { years } \quad 2<\text { years }<5
$$$$
5<\text { years }
$$

\section{Section II. Questions relating to the QMS implementation}

2.1. The organization sought external consultancy for the QMS implementation*

\begin{tabular}{c|c|}
\hline Yes & $(\rightarrow 2.3)$
\end{tabular}

If yes

What's your opinion on external consultants' role?

\begin{tabular}{|l|l|}
\hline Very useful & Useful \\
\hline
\end{tabular}

Please justify your choice

2.2. Who elaborated the QMS documentation?*
Consultants
Quality manager
Both consultants and quality manager
Other specify

2.3 What were the reasons behind ISO 9001 certification?
$\square$ Competitive pressure
Improving the image of the organization
Breaking into the international market
Improving profitability 
Improving products quality

Maximizing customer satisfaction

Improving performance

Improving the overall organizational management system

Other specify

\section{Section III. Questions relating to obstacles to QMS implementation}

- Please note that the barriers listed below are the most common barriers to quality initiatives in general and ISO 9001 implementation in particular.

- Please tick the appropriate box: Totally disagree, disagree, agree, and totally agree or NA: Not applicable/Not sure.

- The selected answer should represent your own opinion on barriers experienced during implementation in your organization.

- If you have comments about the answers, please write them in the section below each answer.

- If your organization has faced or is currently facing other barriers, please quote them at the end of the questionnaire.

\begin{tabular}{|c|c|c|c|c|c|}
\hline Barrier & Totally disagree & Disagree & Agree & Totally agree & NA \\
\hline Difficulty in understanding ISO 9001 requirements & & & & & \\
\hline \multicolumn{6}{|c|}{ Comment: $\ldots \ldots \ldots \ldots \ldots \ldots \ldots \ldots \ldots \ldots \ldots \ldots \ldots \ldots \ldots \ldots \ldots \ldots \ldots \ldots \ldots \ldots \ldots \ldots \ldots \ldots \ldots \ldots \ldots \ldots \ldots \ldots \ldots \ldots \ldots \ldots \ldots \ldots$} \\
\hline Barrier & Totally disagree & Disagree & Agree & Totally agree & NA \\
\hline \multicolumn{6}{|l|}{$\begin{array}{l}\text { Unawareness of the purpose of certification within } \\
\text { the organization }\end{array}$} \\
\hline \multicolumn{6}{|c|}{ Comment: } \\
\hline Barrier & Totally disagree & Disagree & Agree & Totally agree & NA \\
\hline $\begin{array}{l}\text { Unawareness of the benefits of certification within } \\
\text { the organization }\end{array}$ & & & & & \\
\hline
\end{tabular}

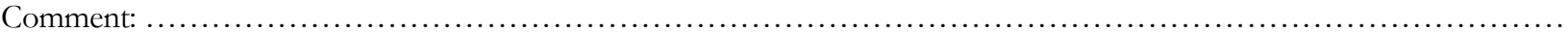

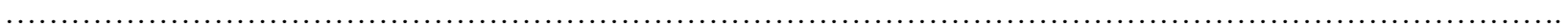

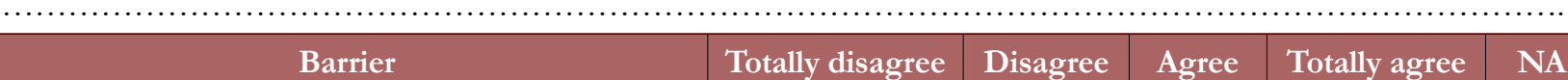

Bad experiences with previous organizational changes

Comment:



\section{Barrier}

Totally disagree $\quad$ Disagree

Agree $\quad$ Totally agree

Lack of time to dedicate to the process of implementation

Comment:

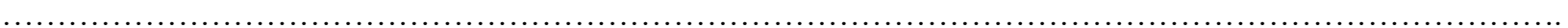

Barrier

Totally disagree Disagree

Agree

Totally agree $\quad$ NA

Lack of employees' knowledge on ISO 9001 standard

Comment: 


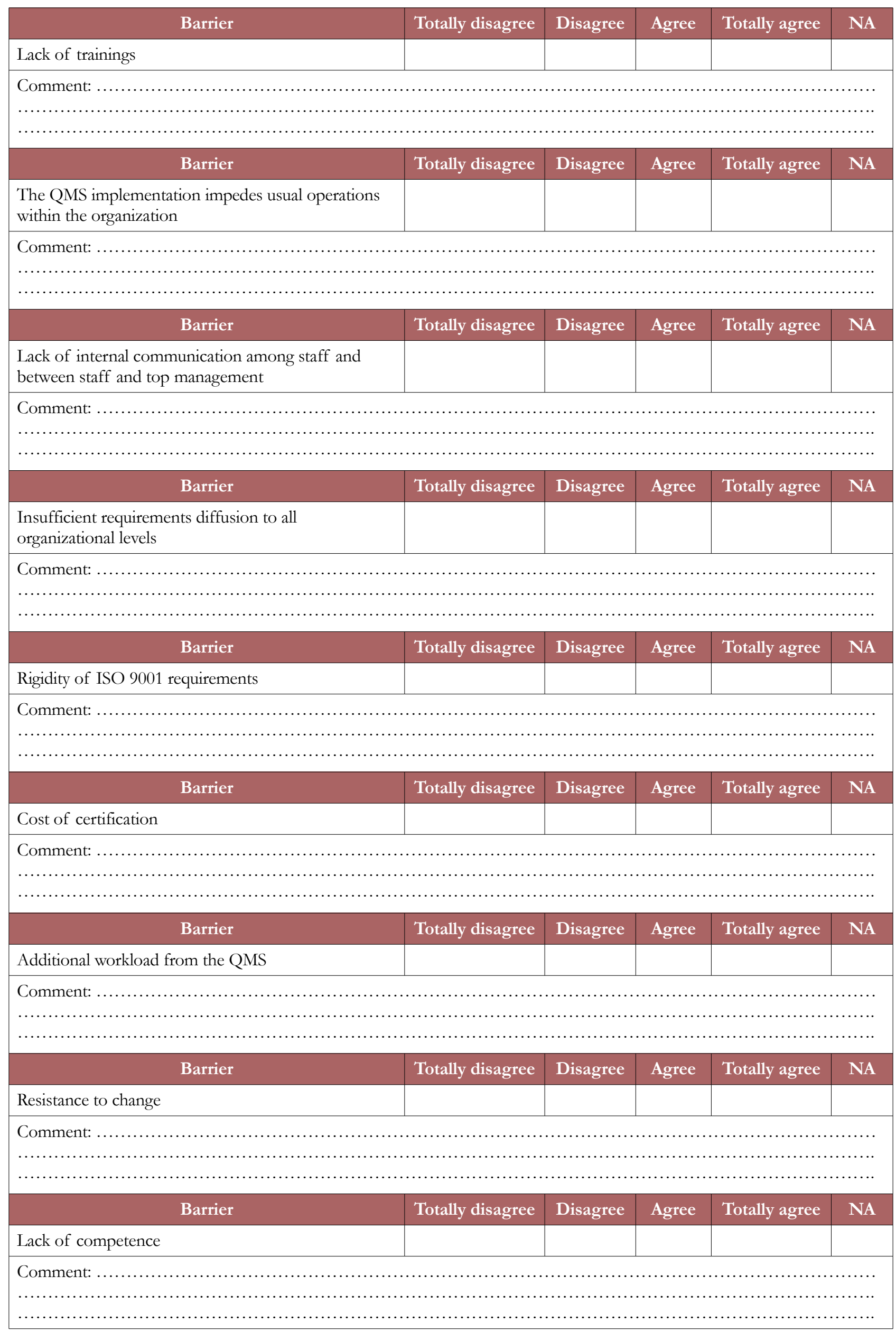




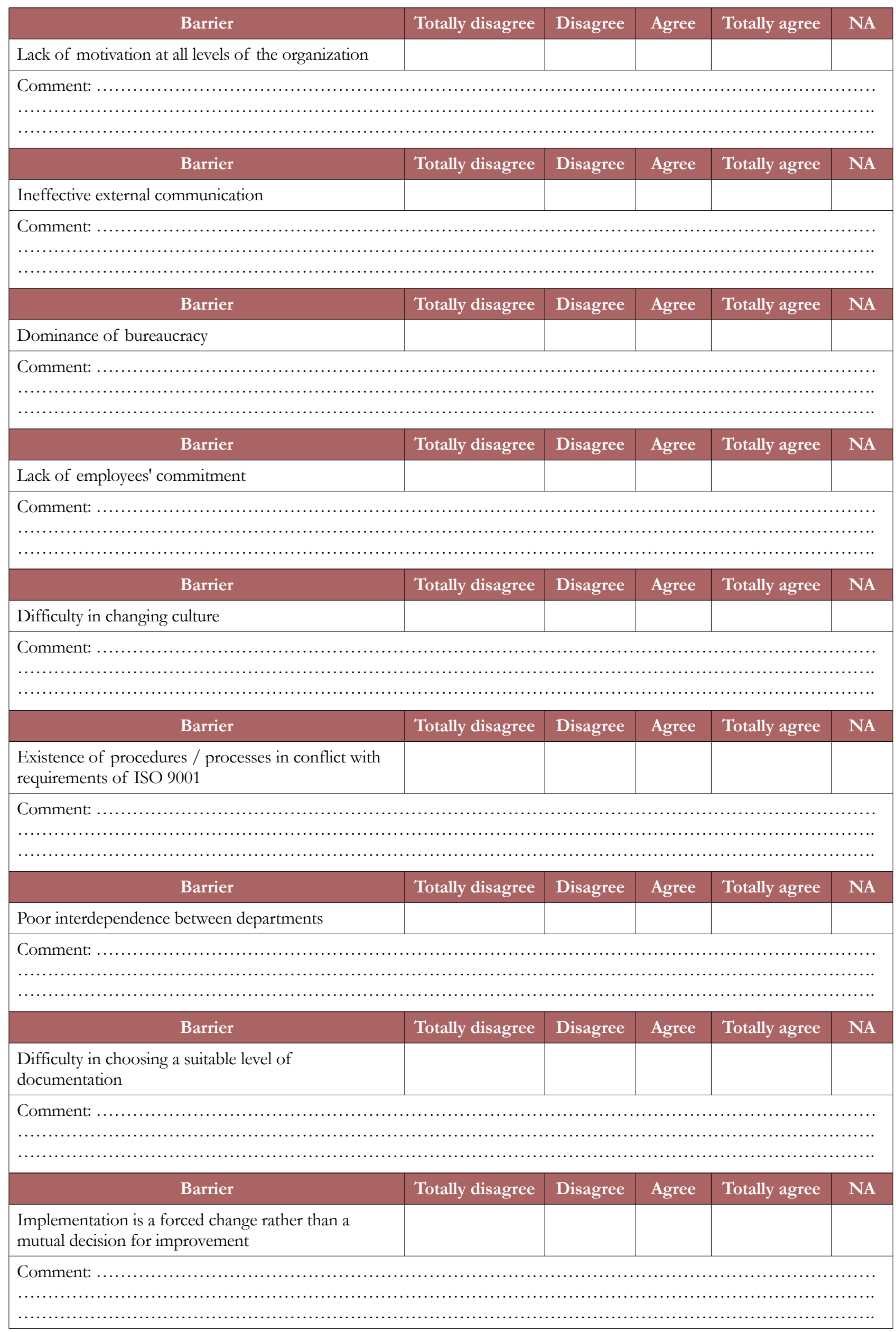




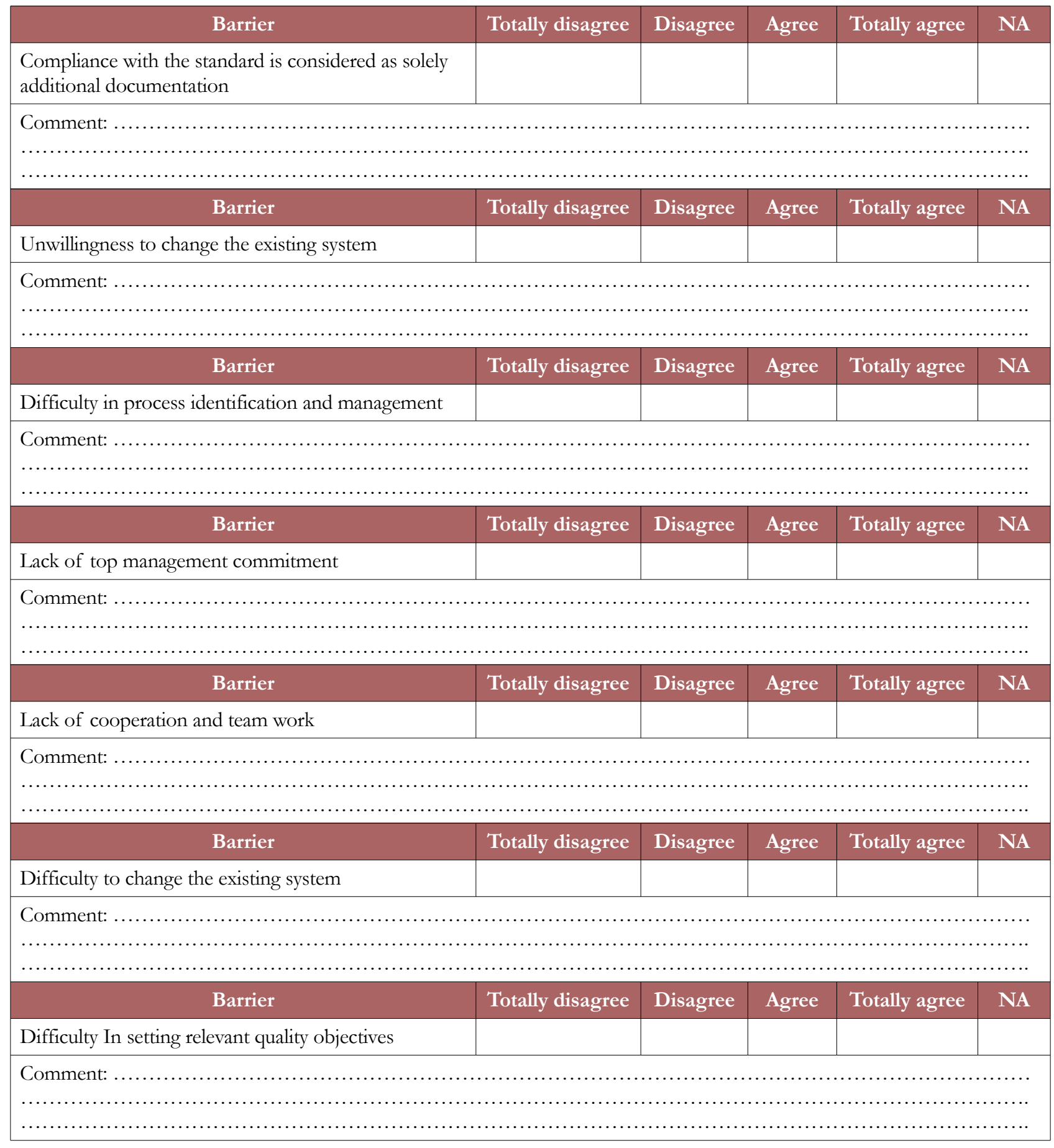

Q: Please mention any other barrier to the QMS implementation within the organization? 


\section{Annex B: Ranking of all the assested barriers}

\begin{tabular}{|c|c|c|}
\hline Barriers & Mean & Ranking \\
\hline Resistance to change & 3.479 & 1 \\
\hline Poor interdependence between departments & 3.064 & 2 \\
\hline Lack of top management commitment & 3.043 & 3 \\
\hline Dominance of bureaucracy & 2.947 & 4 \\
\hline Lack of internal communication among staff and between staff and top management & 2.840 & 5 \\
\hline Insufficient requirements diffusion to all organizational levels & 2.798 & 6 \\
\hline Lack of trainings & 2.796 & 7 \\
\hline Difficulty in changing culture & 2.777 & 8 \\
\hline Difficulty in process identification and management & 2.630 & 9 \\
\hline Unawareness of the benefits of certification within the organization & 2.482 & 10 \\
\hline Difficulty to change the existing system & 2.409 & 11 \\
\hline Compliance with the standard is considered as solely additional documentation & 2.395 & 12 \\
\hline Lack of employees' commitment & 2.348 & 13 \\
\hline Implementation is a forced change rather than a mutual decision for improvement & 2.296 & 14 \\
\hline Unwillingness to change the existing system & 2.226 & 15 \\
\hline Lack of motivation at all levels of the organization & 2.209 & 16 \\
\hline Unawareness of the purposes of certification within the organization & 2.175 & 17 \\
\hline Difficulty of understanding ISO 9001 requirements & 2.104 & 18 \\
\hline Difficulty In setting relevant quality objectives & 2.070 & 19 \\
\hline Difficulty in choosing a suitable level of documentation & 1.896 & 20 \\
\hline Existence of procedures / processes in conflict with requirements of ISO 9001 & 1.791 & 21 \\
\hline Lack of knowledge on ISO 9001 standard for employees & 1.765 & 22 \\
\hline Additional workload from the QMS & 1.765 & 22 \\
\hline Lack of competence & 1.757 & 24 \\
\hline Ineffective external communication & 1.661 & 25 \\
\hline Rigidity of ISO 9001 requirements & 1.652 & 26 \\
\hline Bad experiences with previous organizational changes & 1.496 & 27 \\
\hline Lack of time to dedicate to the process of implementation & 1.504 & 27 \\
\hline The QMS implementation impedes usual operations within the organization & 1.435 & 29 \\
\hline Cost of certification & 1.435 & 29 \\
\hline Lack of cooperation and team work & 1.400 & 31 \\
\hline
\end{tabular}

Most important barriers Least important barriers

Journal of Industrial Engineering and Management, 2018 (www.jiem.org)

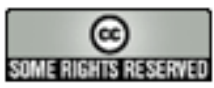

Article's contents are provided on an Attribution-Non Commercial 4.0 Creative commons International License. Readers are allowed to copy, distribute and communicate article's contents, provided the author's and Journal of Industrial Engineering and Management's names are included. It must not be used for commercial purposes. To see the complete license contents, please visit http://creativecommons.org/licenses/by-nc/4.0/. 